\title{
Study of Vibration Exposure from 55 HP Agricultural Tractors in Rotary Tillage Operations
}

\author{
Banasmita Behera*, Ramani Ranjan Pradhan, Santosh Kumar Mohanty \\ and Debaraj Behera
}

Department of Farm Machinery and Power, College of Agricultural Engineering and Technology (CAET), OUAT, Bhubaneswar, India

*Corresponding author

\section{Keywords}

Tractor, Rotavator, Whole body vibration, Hand armvibration

\section{Article Info}

\section{Accepted:}

08 January 2020

Available Online:

10 February 2020

\section{A B S T R A C T}

Tractor is a versatile vehicle designed to deliver high torque at much lower speed. It is mainly used for off-road condition and different field operations. Among these, rotavators are getting popularised as it can be used for both primary and secondary tillage operation as well as both in wet land and dry land operations. It has the capability of producing good quality tillage compared to other tillage operations. However, the impact action of rotavator blades generate very intense vibrations. These vibrations when transmitted to the operator may cause various musculoskeletal disorders. Hence, to evaluate this a study was conducted to evaluate the effect of tractor use hour, operator weight, speed of operation and depth of operation on whole body vibration and hand arm vibration. From the study it was found that, with increase in hours of use vibration increased. The vibration was found lower in $75 \mathrm{~kg}$ operator as compared to $65 \mathrm{~kg}$ and $85 \mathrm{~kg}$ operators. Both whole body vibration and hand arm vibration was observed to be increased with increase in speed of operation. However, the effect of depth of operation was not increased linearly with increase in depth of operation.

\section{Introduction}

Tractor is a versatile vehicle designed to deliver high torque at much lower speed. It is mainly used for off-road condition and different field operations starting from land preparation to harvesting of produces. In India, tractor is mostly used for land preparation by using mould board plough, disc plough, rotavator etc. Among these, rotavators are getting popularised as it can be used for both primary and secondary tillage 
operation as well as both in wet land and dry land operations. It has the capability of producing good quality tillage compared to other tillage operations (Prakash et al., 2013). The tractor operated machines creates vibration and rotavator is of no exception (Mehta et al., 1997). The rotavator blades cuts the soil slice by impact action or slicing action depending on the design of the blades. This generates very intense vibration which is then transmitted to the operator through various parts like seat suspension, steering wheel, sitting platform, hand control knobs etc (Village et al., 2012). The important factors that has significant effect on vibration are forward speed of tractor and uneven ground condition (Oude vrielink, 2009). Among the different form of vibration generated, the vibration transmitted to the operators' body to the seat from the feet via the chassis and to the hand arm system from the steering wheel (Goglia et al., 2003). Tractor operation becomes more critical at the frequency range $1-7 \mathrm{~Hz}$ as resonance occurs in between these frequency ranges (Kumar et $a l ., 2001)$. These frequency range may cause musculoskeletal disorders among the operators mostly in the back region of the operators (Prakash et al., 2013). The occupational low back pain is predominant among the tractor operators due to exposure of whole body vibration (Boshulzen et al., 1990). Hand arm vibration may cause damage to fingers i.e. white finger diseases, numbness and carpel tunnel syndrome (Griffin, 1996). From evaluation and analysis of the ride comfort during soil tillage operation, it was found that the forward speed of operation has greater impact on vibration transmission to the operator (Singh et al., 2019). Another study confirmed that, the effect of vibration is predominant for rotavator operation compared to soil tillage operations (Dewangan et al.). During ploughing condition, the hand arm vibration in frequency range of $1-20 \mathrm{~Hz}$ and $40-80 \mathrm{~Hz}$ was found to have very critical effect on operator ( Zaka et al., 2015). Very few research work was done in effect of vibration during rotary tillage operation. Hence, the present study focuses on the effect of speed of operation and depth of operation on both hand arm vibration and whole body vibration and also the effect of operator's weight on whole body vibration.

\section{Materials and Methods}

\section{Field condition}

The field experiments were conducted in the field available in Central Farm of Odisha University of Agriculture and Technology, Bhubaneswar. Two fields were selected for the study one for dry tillage and another for wet tillage. To evaluate the effect of speed of operation and depth of operation, three different levels of each parameter were selected. Table 1 shows the selected speed of operation and depth of operation for rototilling operation in both fields. The recommended speed of operation was $3 \mathrm{kmph}$ and $2 \mathrm{kmph}$ during dry tillage and wet tillage operation, respectively. Hence, the speed of operation selected were one level above and below the recommended speed. Similarly, the recommended depth of operation was $12 \mathrm{~cm}$ and $15 \mathrm{~cm}$ for dry and wet field operation, respectively. Hence the depths selected were $8 \mathrm{~cm}, 12 \mathrm{~cm}$ and $16 \mathrm{~cm}$ for dry field and 12 $\mathrm{cm}, 15 \mathrm{~cm}$ and $18 \mathrm{~cm}$ for wet field operation.

\section{Selection of tractor and rotavator}

Two $55 \mathrm{hp}$ PTO power tractors available in Odisha University of Agriculture and Technology were selected for the vibration study. They were selected in such a way that the effect of hours of use on vibration can be evaluated. The first tractor selected was new one with hours of use less than 50 hours whereas the other tractor had more than 5000 hours of use. Fig. 2 shows the tractors 
selected for the study. The detailed specifications of the tractors are shown in Table 2. Both the tractors were fitted with 1.2 $m$ width rotavator. The detailed specifications of the rotavator is presented in Table 3 .

\section{Selection of subjects}

The tractor seat was designed to seat operator's weight of 50 to $120 \mathrm{~kg}$. Hence, three operators were selected in the weight range $60-70 \mathrm{~kg}, 70-80 \mathrm{~kg}$ and $80-90 \mathrm{~kg}$. The operators were selected to evaluate the effect of operators' weight on vibration. Table 4 shows the weight, height, body surface area (BSA) and body mass index (BMI) of the selected operators.

\section{Vibration measurement}

For vibration measurement, accelerometer was used. The complete setup includes accelerometer, module, battery and data acquisition system. The complete setup is shown in Fig 3. The detailed specification of the tri-axial accelerometer is given in Table 5 . The used accelerometer was apiezo-resistive type. The sensing element consists of a very small mass and a flexure element cantilevered between two plates. Due to vibration, the deflected mass impacts a force which was measured by strain gauge. The AC excitation and amplitude demodulation circuit present in the accelerometer gives an analogue voltage output that is proportional to the applied acceleration. The output signal from accelerometer acts as input for the NI 9215 module where the signals were converted to acceleration values. The module was connected to a data acquisition system through a USB cable. The data were collected by using DEWESOFT software interface where 5000 vibration data were collected per second. To measure the transmitted whole body vibration, first the accelerometer was placed above the seat cushion of tractor seat.
Similarly, to measure hand arm vibration transmitted through steering wheel, the accelerometer was attached to the steering wheel firmly. Fig 4 shows the accelerometer locations for vibration measurement. For each condition of vibration measurement, ten numbers of replications were done.

\section{Vibration analysis}

The vibration data was analysed as per ISO 2631:1991 and ISO 5349-1:2001. First peak data were collected in time domain and then it was converted to frequency domain by fast fourier transform. The peak data were converted to RMS acceleration data. The frequency domain data was again converted to $1 / 3^{\text {rd }}$ octave band data and human weightage was applied as given in the above mention standards. To calculate the overall weighted vibration, the data selected for whole body vibration was $1-80 \mathrm{~Hz}$ and that for hand arm vibration were 50-1000 Hz. Then the overall weighted vibration data was calculated by the formula given below.

$$
\begin{aligned}
& a_{w i}=\sum a_{i} w_{i}^{2} \\
& a=\sqrt{\left(k_{x} a_{w x}\right)^{2}+\left(k_{y} a_{w y}\right)^{2}+\left(k_{z} a_{w z}\right)^{2}}
\end{aligned}
$$

\section{Where}

$\mathrm{a}_{\text {wi }}=$ weighted RMS acceleration

$\mathrm{a}_{\mathrm{i}}=$ RMS acceleration in $i^{\text {th }}$ frequency

$\mathrm{W}_{\mathrm{i}}=$ weightage of $\mathrm{i}^{\text {th }}$ frequency

$\mathrm{a}_{w x x}, \mathrm{a}_{w y}$ and $\mathrm{a}_{w z}=$ weighted RMS acceleration in $\mathrm{x}, \mathrm{y}$ and $\mathrm{z}$ axis, respectively

$\mathrm{a}=$ overall acceleration

$\mathrm{k}_{\mathrm{x}}, \mathrm{k}_{\mathrm{y}}$ and $\mathrm{k}_{\mathrm{z}}=$ multiplying factors

$\mathrm{k}_{\mathrm{x}}, \mathrm{k}_{\mathrm{y}}=1.4$ and $\mathrm{k}_{\mathrm{z}}=1$ for whole body vibration

$\mathrm{k}_{\mathrm{x}}, \mathrm{k}_{\mathrm{y}}$ and $\mathrm{k}_{\mathrm{z}}=1$ for hand arm vibration

$\mathrm{n}, \mathrm{k}=$ limits of vibration 
$\mathrm{i}=0.5$ to $80 \mathrm{~Hz}$ for whole body vibration and

$\mathrm{i}=50$ to $1000 \mathrm{~Hz}$ for hand arm vibration

\section{Limits of whole vibration exposure}

As per EU DIRECTIVE 2002/44/EC, for better performance of the operator, the limit of whole body and hand arm vibration exposure should not be exceeded as the value given below. Exposure action value (EAV) is defined as the level of daily exposure set out for any worker if exceeded, then the necessary action should be taken to reduce the risk and exposure limit value is defined as the level of daily exposure that should not be exceeded

\section{Results and Discussion}

The whole body vibration and hand arm vibration was measured during rotavator operation in dry field condition and wet field condition. To evaluate the effect of operator's weight, speed of operation and depth of operation, the tractors were tested at three different levels for each of the following parameters. For each condition four numbers of replication were done. Table 7 shows the ANOVA (Analysis of Variance) of the measured WBV data. In the table factor A, B, $\mathrm{C}, \mathrm{D}$ and $\mathrm{E}$ represents terrain type, tractor type, speed of operation, operator's weight and depth of operation, respectively. From the table it can be clearly seen that, the main effect of factors B, C and D on WBV were significantly different at both 5 per cent and 1 per cent level of significance whereas that of factor $\mathrm{A}$ and $\mathrm{E}$ were significantly different at only 5 per cent level of significance. All the interaction effects were significantly different at both 5 per cent and 1 per cent level of significance except those where factor A and $\mathrm{E}$ were on the parameter. In those levels, they were significantly different at only 5 per cent level of significance. While considering multiple interactions, the data were significantly different at both level of significance.

Table 8 shows the ANOVA result of the HAV. Here the main factors were terrain type (A), tractor type (B), speed of operation (C) and depth of operation (E). Here, the operator's weight was not a parameter as there is no effect of this on HAV. From the table it can be clearly seen that the main effect of factor $\mathrm{B}$ and $\mathrm{C}$ was significantly different at both 5 per cent and 1 per cent level of significance whereas that of factor $\mathrm{A}$ and $\mathrm{E}$ was significantly different at only 5 per cent level of significance. Similarly, as in WBV, the interaction effects were significantly different both 5 and 1 per cent level of significance except those where factor $\mathrm{A}$ and factor $\mathrm{E}$ were one the interaction parameter.

\section{Effect of speed of operation on vibration}

Overall weighted RMS vibration acceleration for both WBV and HAV was found to be increased with increase in speed of operation, which is shown in Table 9. In both field, with increase in speed of operation, the WBV and HAV was found to be increased significantly which was due to increased occurrence of ground undulation at higher speed. However, the percentage increase in vibration was higher in dry field as compared to wet field operation which may be due to the more cushioning effect of wet field as compared to dry field. This was because of presence of standing water and higher moisture content of the wet soil. With increase in speed of operation, the overall weighted WBV for tractor 1 increased from $1.10 \mathrm{~m} / \mathrm{s}^{2}$ to 1.42 $\mathrm{m} / \mathrm{s}^{2}$ with a percentage increase of 29.09 per cent for dry field and $0.97 \mathrm{~m} / \mathrm{s}^{2}$ to $1.22 \mathrm{~m} / \mathrm{s}^{2}$ with a percentage increase of 25.77 per cent. For tractor 2, it was increased from $1.39 \mathrm{~m} / \mathrm{s}^{2}$ to $1.62 \mathrm{~m} / \mathrm{s}^{2}$ with a percentage increase of 16.54 per cent in dry field and $1.17 \mathrm{~m} / \mathrm{s}^{2}$ to $1.31 \mathrm{~m} / \mathrm{s}^{2}$ with a percentage increase of 11.96 
per cent. Similarly, the HAV in tractor 1 increased from $2.53 \mathrm{~m} / \mathrm{s}^{2}$ to $3.30 \mathrm{~m} / \mathrm{s}^{2}$ with a percentage increase of 30.43 per cent in dry field and $2.42 \mathrm{~m} / \mathrm{s}^{2}$ to $2.93 \mathrm{~m} / \mathrm{s}^{2}$ with a percentage increase of 21.07 per cent in wet field.

\section{Effect of depth of operation on vibration}

Overall weighted RMS vibration acceleration for both WBV and HAV was observed to be decreased with increase in depth of operation in dry field as well as wet field rototilling operation (Table 10). This was due to increase depth of operation increase load on the rotavator blades as well as on the tractor. As a result, the tractor parts vibrates less at higher depth and less vibration was transmitted to the operator seat as well as to steering wheel of tractor. With increase in depth of operation, the overall weighted $\mathrm{WBV}$ for tractor 1 decreased from $1.29 \mathrm{~m} / \mathrm{s}^{2}$ to $1.09 \mathrm{~m} / \mathrm{s}^{2}$ with a percentage decrease of 15.50 per cent for dry field and $1.16 \mathrm{~m} / \mathrm{s}^{2}$ to $0.98 \mathrm{~m} / \mathrm{s}^{2}$ with a percentage decrease of 15.51 per cent. For tractor 2 , it was decreased from $1.54 \mathrm{~m} / \mathrm{s}^{2}$ to $1.31 \mathrm{~m} / \mathrm{s}^{2}$ with a percentage decrease of 14.93 per cent in dry field and $1.27 \mathrm{~m} / \mathrm{s} 2$ to 1.08 $\mathrm{m} / \mathrm{s} 2$ with a percentage decrease of 14.96 per cent. Similarly, the HAV in tractor 1 decreased from $2.63 \mathrm{~m} / \mathrm{s}^{2}$ to $2.29 \mathrm{~m} / \mathrm{s}^{2}$ with a percentage increase of 12.92 per cent in dry field and $2.54 \mathrm{~m} / \mathrm{s}^{2}$ to $2.15 \mathrm{~m} / \mathrm{s}^{2}$ with a percentage decrease of 15.35 per cent in wet field. For tractor 2, HAV was observed to be decreased from $2.92 \mathrm{~m} / \mathrm{s}^{2}$ to $2.42 \mathrm{~m} / \mathrm{s}^{2}$ with a percentage decrease of 16.43 per cent in dry field and $2.84 \mathrm{~m} / \mathrm{s}^{2}$ to $2.37 \mathrm{~m} / \mathrm{s}^{2}$ with a percentage decrease of 16.54 per cent.

\section{Effect of operators' weight on vibration}

Table.11 shows that with increase in operator's weight, the vibration value increases but not linearly as the vibration value was more for operator of weight $85 \mathrm{~kg}$ than $75 \mathrm{~kg}$ but it was more in $65 \mathrm{~kg}$ than 75 $\mathrm{kg}$ operator. This pattern of vibration was observed for both the tractor during dry field as well as in wet tillage operation. For $65 \mathrm{~kg}$ operator, the seat suspension acts as hard surface and transmit the vibration to the operator seat without any reduction. But for $85 \mathrm{~kg}$ operator, the seat suspension behaves like soft medium which takes more time to dampen the vibration and increases the amount of vibration transmitted to the operator. In tractor 1 , the overall weighted RMS vibration acceleration was found to be $1.19 \mathrm{~m} / \mathrm{s}^{2}, 1.10 \mathrm{~m} / \mathrm{s}^{2}, 1.34 \mathrm{~m} / \mathrm{s}^{2}$ in dry field and $1.08 \mathrm{~m} / \mathrm{s}^{2}, 0.93 \mathrm{~m} / \mathrm{s}^{2}$ and $1.14 \mathrm{~m} / \mathrm{s}^{2}$ in wet field for $65 \mathrm{~kg}, 75 \mathrm{~kg}$ and $85 \mathrm{~kg}$ operator, respectively. Similarly, while rototilling operation with tractor 2 , the WBV was found to be $1.30 \mathrm{~m} / \mathrm{s}^{2}, 1.24 \mathrm{~m} / \mathrm{s}^{2}, 1.47 \mathrm{~m} / \mathrm{s}^{2}$ in dry field and $1.16 \mathrm{~m} / \mathrm{s}^{2}, 1.10 \mathrm{~m} / \mathrm{s}^{2}, 1.34 \mathrm{~m} / \mathrm{s}^{2}$ in wet field for $65 \mathrm{~kg}, 75 \mathrm{~kg}, 85 \mathrm{~kg}$ operator, respectively.

\section{Effect of number of hour use of tractor and field conditionon vibration}

Fig 8 shows the vibration value in both the tractor during dry tillage and wet field operation. In dry field, the soil cone index was found to be $100 \mathrm{kPa}$ whereas for wet field it was less than $20 \mathrm{kPa}$. The wet field had also standing water of depth around $10 \mathrm{~cm}$. Hence, during rotavator operation in wet field, some of blade generated vibrations was absorbed by the standing water and soft soil. This results in less vibration transmitted to the operator in wet field as compared to dry field where the soil was harder one. From fig.8, it was found that tractor 1 transmit more vibration as compared to tractor 2. The hours of use of tractor 2 was more than 5000 hours whereas that of tractor 1 was less than 200 hours. With increase in hours of use, some parts of the tractor get worn out, which creates more vibratory motion and transmit more vibration to the operator. In dry field operation, the 
WBV was found to be $1.34 \mathrm{~m} / \mathrm{s}^{2}, 1.65 \mathrm{~m} / \mathrm{s}^{2}$ and HAV was $3.23 \mathrm{~m} / \mathrm{s}^{2}, 3.48 \mathrm{~m} / \mathrm{s}^{2}$ for tractor 1 and tractor 2, respectively. Similarly, in wet field operation, the WBV was $1.21 \mathrm{~m} / \mathrm{s}^{2}, 1.47$ $\mathrm{m} / \mathrm{s}^{2}$ and HAV was $2.98 \mathrm{~m} / \mathrm{s}^{2}$ and $3.29 \mathrm{~m} / \mathrm{s}^{2}$ for tractor 1 and tractor 2 , respectively.

Table.1 Field condition, speed and depth of operation

\begin{tabular}{|c|c|c|c|c|c|c|}
\hline Field & \multicolumn{3}{|c|}{ Speed, kmph } & \multicolumn{3}{|c|}{ Depth, cm } \\
\hline Dry field & $2\left(\mathrm{~S}_{\mathrm{d} 1}\right)$ & $3\left(S_{\mathrm{d} 2}\right)$ & $4\left(\mathrm{~S}_{\mathrm{d} 3}\right)$ & $8\left(\mathrm{D}_{\mathrm{d} 1}\right)$ & $12\left(\mathrm{D}_{\mathrm{d} 2}\right)$ & $16\left(\mathrm{D}_{\mathrm{d} 3}\right)$ \\
\hline Wet field & $1\left(\mathrm{~S}_{\mathrm{w} 1}\right)$ & $2\left(S_{\mathrm{w} 2}\right)$ & $3\left(\mathrm{~S}_{\mathrm{w} 3}\right)$ & $12\left(\mathrm{D}_{\mathrm{w} 1}\right)$ & $15\left(\mathrm{D}_{\mathrm{w} 2}\right)$ & $18\left(\mathrm{D}_{\mathrm{w} 3}\right)$ \\
\hline
\end{tabular}

Table.2 Specification of tractors selected for the study

\begin{tabular}{|c|c|c|}
\hline & Tractor 1 & Tractor 2 \\
\hline Make & John Deere (JD) & New Holland (NH) \\
\hline Model & 5310 & 5500 \\
\hline Rated power, $\mathbf{k W}$ & 55 & 55 \\
\hline Number of hour use, $h$ & 1056 & 116 \\
\hline Number of cylinder & 3 & 3 \\
\hline Rated rpm & 2400 & 2300 \\
\hline Air filter & Dry air cleaner & Dry air cleaner \\
\hline Clutch & Synchromesh & $\begin{array}{l}\text { Constant mesh, partial } \\
\text { synchromesh }\end{array}$ \\
\hline Gear box & $9 F+3 R$ & $8 F+2 R$ \\
\hline Brake & Oil immersed multi disc & $\begin{array}{l}\text { Oil immersed multi disc } \\
\text { brake }\end{array}$ \\
\hline Steering & Power & Power \\
\hline PTO type & Multi speed PTO & Ground speed PTO \\
\hline PTO rpm & 540 & 540 \\
\hline Fuel tank capacity, L & 68 & 63 \\
\hline Weight,kg & 2110 & 2220 \\
\hline Wheel base, mm & 2050 & 2055 \\
\hline Overall length, mm & 3535 & 3500 \\
\hline Overall width, mm & 1850 & 1925 \\
\hline Ground clearance, $\mathbf{m m}$ & 435 & 470 \\
\hline $\begin{array}{l}\text { Hydraulic lifting capacity, } \\
\text { kg }\end{array}$ & 2000 & 2400 \\
\hline Drive & $2 \mathrm{WD}$ & $4 \mathrm{WD}$ \\
\hline Front tyre & $6.5 \times 20$ & $9.25 \times 16$ \\
\hline Rear tyre & $16.9 \times 28$ & $16.9 \times 28$ \\
\hline
\end{tabular}


Table.3 Specification of rotavator

\begin{tabular}{|l|c|}
\hline Make & Maschio gasoardo \\
\hline Model & Virat v185 \\
\hline Power of tractor & $30-75 \mathrm{hp}$ \\
\hline Blade type & L- type \\
\hline Rpm of gear box & 540 \\
\hline Weight & $550 \mathrm{~kg}$ \\
\hline Working width, mm & 160 to 185 \\
\hline Working depth, mm & 120 to 17.5 \\
\hline Speed & Multi speed \\
\hline Type of drive & Gear \\
\hline Number of blades & 42 \\
\hline
\end{tabular}

Table.4 Physiological parameter of operators selected for the study

\begin{tabular}{|c|c|c|c|}
\hline Particulars & Operator 1 & Operator 2 & Operator 3 \\
\hline Weight, kg & 65 & 75 & 85 \\
\hline Height, cm & 165 & 158 & 162 \\
\hline BSA, $\mathbf{m}^{2}$ & 1.38 & 1.57 & 1.78 \\
\hline BMI, $\mathrm{kg} / \mathrm{m}^{2}$ & 39.85 & 41.40 & 42.13 \\
\hline
\end{tabular}

Table.5 Detailed specification of Tri-axial accelerometer

\begin{tabular}{|l|c|}
\hline Make & Bruel and Kjaer \\
\hline Mass, $\mathbf{g}$ & 30 \\
\hline Frequency range, $\mathbf{H z}$ & $0-1000$ \\
\hline Measurement range & $50 \mathrm{~g}\left(\mathrm{~g}=9.81 \mathrm{~m} / \mathrm{s}^{2}\right)$ \\
\hline Temperature range, ${ }^{\mathbf{0}} \mathrm{C}$ & -55 to 125 \\
\hline Sensitivity, $\mathbf{g} / \mathbf{v}$ & 0.002 \\
\hline
\end{tabular}

Table.6 Vibration exposure limits as per EU Directive

\begin{tabular}{|l|c|c|}
\hline & Whole body vibration & Hand arm vibration \\
\hline EAV & $0.5 \mathrm{~m} / \mathrm{s}^{2}$ & $2.5 \mathrm{~m} / \mathrm{s}^{2}$ \\
\hline ELV & $1.15 \mathrm{~m} / \mathrm{s}^{2}$ & $5 \mathrm{~m} / \mathrm{s}^{2}$ \\
\hline
\end{tabular}


Table.7 ANOVA result of WBV data during rotavator operation

\begin{tabular}{|l|c|l|l|l|}
\hline Sources of variation & Degree of freedom & $\begin{array}{c}\text { Mean } \\
\text { square }\end{array}$ & F-value & P value \\
\hline A & 1 & 0.000 & 4.86 & 0.021 \\
\hline B & 1 & 0.287 & 2258.34 & 0.000 \\
\hline C & 2 & 0.013 & 44.98 & 0.000 \\
\hline D & 2 & 0.035 & 591.60 & 0.000 \\
\hline E & 2 & 0.000 & 3.83 & 0.035 \\
\hline A X B & 1 & 0.000 & 3.48 & 0.031 \\
\hline A X C & 2 & 0.000 & 4.36 & 0.013 \\
\hline A X D & 2 & 0.000 & 3.54 & 0.027 \\
\hline A X E & 2 & 0.000 & 4.52 & 0.018 \\
\hline B X C & 2 & 0.053 & 982.52 & 0.000 \\
\hline B X D & 2 & 0.048 & 987.13 & 0.000 \\
\hline B X E & 2 & 0.341 & 3259.78 & 0.000 \\
\hline C X D & 4 & 0.005 & 248.98 & 0.000 \\
\hline C X E & 4 & 0.026 & 52.30 & 0.000 \\
\hline D X E & 4 & 0.037 & 836.08 & 0.000 \\
\hline A X B X C & 2 & 0.000 & 7.83 & 0.000 \\
\hline A X B X D & 2 & 0.002 & 13.68 & 0.000 \\
\hline A X C X D & 4 & 0.000 & 5.87 & 0.002 \\
\hline B X C X D & 4 & 0.035 & 649.00 & 0.000 \\
\hline A X B X C X D & 4 & 0.000 & 9.61 & 0.000 \\
\hline A X B X C X D X E & 8 & 0.000 & 12.98 & 0.000 \\
\hline Error & 51 & & & \\
\hline
\end{tabular}

Table.8 ANOVA result of HAV data during rotavator operation

\begin{tabular}{|l|c|l|l|l|}
\hline Sources of variation & $\begin{array}{c}\text { Degree of } \\
\text { freedom }\end{array}$ & $\begin{array}{c}\text { Mean } \\
\text { square }\end{array}$ & F-value & P value \\
\hline A & 1 & 0.000 & 4.86 & 0.021 \\
\hline B & 1 & 0.287 & 2258.34 & 0.000 \\
\hline C & 2 & 0.013 & 44.98 & 0.000 \\
\hline E & 2 & 0.000 & 3.83 & 0.035 \\
\hline A X B & 1 & 0.000 & 3.48 & 0.031 \\
\hline A X C & 2 & 0.000 & 4.36 & 0.013 \\
\hline A X E & 2 & 0.000 & 4.52 & 0.018 \\
\hline B X C & 2 & 0.053 & 982.52 & 0.000 \\
\hline B X E & 2 & 0.341 & 3259.78 & 0.000 \\
\hline C X E & 4 & 0.026 & 52.30 & 0.000 \\
\hline D X E & 4 & 0.037 & 836.08 & 0.000 \\
\hline A X B X C & 2 & 0.000 & 7.83 & 0.000 \\
\hline A X B X C X E & 4 & 0.000 & 9.613 & 0.000 \\
\hline Error & 7 & & & \\
\hline
\end{tabular}


Table.9 Effect of speed of operation on vibration

\begin{tabular}{|c|c|c|c|c|c|c|c|c|c|}
\hline & & \multicolumn{4}{|c|}{ Dry field, $\mathbf{m} / \mathbf{s}^{2}$} & \multicolumn{4}{|c|}{ Wet field, $\mathrm{m} / \mathrm{s}^{2}$} \\
\hline & $\begin{array}{l}\text { Speed, } \\
\text { kmph }\end{array}$ & $\left(\mathbf{S}_{\mathrm{d} 1}\right)$ & $\left(\mathbf{S}_{\mathrm{d} 2}\right)$ & $\left(\mathbf{S}_{\mathrm{d} 3}\right)$ & $\begin{array}{c}\% \text { increase from } \\
S_{\mathrm{d} 1} \text { to } S_{\mathrm{d} 3}\end{array}$ & $\left(\mathbf{S}_{\mathrm{w} 1}\right)$ & $\left(\mathbf{S}_{\mathrm{w} 2}\right)$ & $\left(\mathbf{S}_{\mathrm{w} 3}\right)$ & $\begin{array}{l}\% \% \text { increast } \\
\text { from } S_{\mathrm{w} 1} \text { to } S_{\mathrm{w} 3}\end{array}$ \\
\hline \multirow{2}{*}{$\mathbf{T}_{1}$} & WBV & 1.10 & 1.24 & 1.42 & 29.09 & 0.97 & 1.12 & 1.22 & 25.77 \\
\hline & HAV & 2.53 & 2.69 & 3.30 & 30.43 & 2.42 & 2.53 & 2.93 & 21.07 \\
\hline \multirow[t]{2}{*}{$\mathbf{T}_{2}$} & WBV & 1.39 & 1.30 & 1.62 & 16.54 & 1.17 & 1.25 & 1.31 & 11.96 \\
\hline & HAV & 2.98 & 3.12 & 3.45 & 15.77 & 2.83 & 2.97 & 3.18 & 12.36 \\
\hline
\end{tabular}

Table.10 Effect of depth of operation on vibration

\begin{tabular}{|c|c|c|c|c|c|c|c|c|c|}
\hline & & \multicolumn{4}{|c|}{ Dry field, $\mathrm{m} / \mathrm{s}^{2}$} & \multicolumn{4}{|c|}{ Wet field, $\mathbf{m} / \mathbf{s}^{2}$} \\
\hline & $\begin{array}{c}\text { Depth, } \\
\text { cm }\end{array}$ & $\left(\mathbf{D}_{\mathrm{d} 1}\right)$ & $\left(\mathbf{D}_{\mathrm{d} 2}\right)$ & $\left(\mathbf{D}_{\mathrm{d} 2}\right)$ & $\begin{array}{c}\% \text { decrease } \\
\text { from } D_{d 1} \text { to } D_{d 3}\end{array}$ & $\left(D_{\mathrm{w} 1}\right)$ & $\left(D_{\mathrm{w} 2}\right)$ & $\left(\mathbf{D}_{\mathrm{w} 3}\right)$ & $\begin{array}{c}\% \text { decrease } \\
\text { from } D_{w 1} \text { to } D_{w 3}\end{array}$ \\
\hline \multirow[t]{2}{*}{$\mathbf{T}_{1}$} & WBV & 1.29 & 1.17 & 1.09 & 15.50 & 1.16 & 1.10 & 0.98 & 15.51 \\
\hline & HAV & 2.63 & 2.57 & 2.29 & 12.92 & 2.54 & 2.31 & 2.15 & 15.35 \\
\hline \multirow[t]{2}{*}{$\mathbf{T}_{2}$} & WBV & 1.54 & 1.37 & 1.31 & 14.93 & 1.27 & 1.18 & 1.08 & 14.96 \\
\hline & HAV & 2.92 & 2.79 & 2.44 & 16.43 & 2.84 & 2.70 & 2.37 & 16.54 \\
\hline
\end{tabular}

Table.11 Effect of weight of operator on vibration

\begin{tabular}{|l|c|c|c|c|c|c|}
\hline & \multicolumn{3}{|c|}{ Dry field, $\mathbf{~ m} / \mathbf{s}^{\mathbf{2}}$} & \multicolumn{3}{c|}{ Wet field, $\mathbf{~ m / \mathbf { s } ^ { 2 }}$} \\
\hline & $\mathbf{6 5} \mathbf{~ k g}$ & $\mathbf{7 5} \mathbf{~ k g}$ & $\mathbf{8 5} \mathbf{~ k g}$ & $\mathbf{6 5} \mathbf{~ k g}$ & $\mathbf{7 5} \mathbf{~ k g}$ & $\mathbf{8 5} \mathbf{~ k g}$ \\
\hline $\mathbf{T 1}$ & 1.19 & 1.10 & 1.34 & 1.08 & 0.93 & 1.14 \\
\hline T2 & 1.30 & 1.24 & 1.47 & 1.16 & 1.10 & 1.34 \\
\hline
\end{tabular}

Table.12 Values of limit fatigue according to ISO 2631: 1991

\begin{tabular}{|c|c|c|c|}
\hline Field condition & Tractor type & Operator weight, kg & Limit fatigue, $h$ \\
\hline \multirow{6}{*}{ Dry field } & \multirow{3}{*}{ Tractor 1} & 65 & 4 \\
\hline & & 75 & 4 \\
\hline & & 85 & 4 \\
\hline & \multirow[t]{3}{*}{ Tractor 2} & 65 & 4 \\
\hline & & 75 & 4 \\
\hline & & 85 & 4 \\
\hline \multirow[t]{6}{*}{ Wet field } & \multirow[t]{3}{*}{ Tractor 1} & 65 & 4 \\
\hline & & 75 & 4 \\
\hline & & 85 & 4 \\
\hline & \multirow{3}{*}{ Tractor 2} & 65 & 4 \\
\hline & & 75 & 4 \\
\hline & & 85 & 4 \\
\hline
\end{tabular}




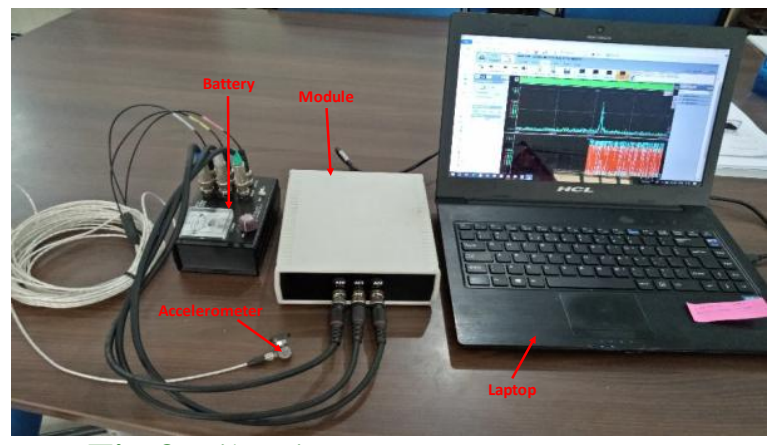

Fig.3 Vibration measurement set up

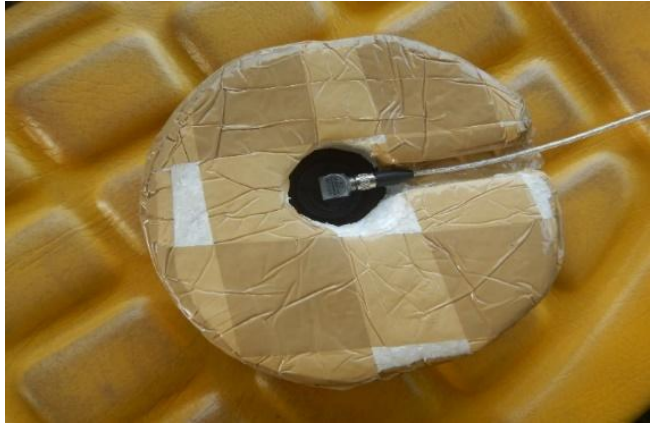

A

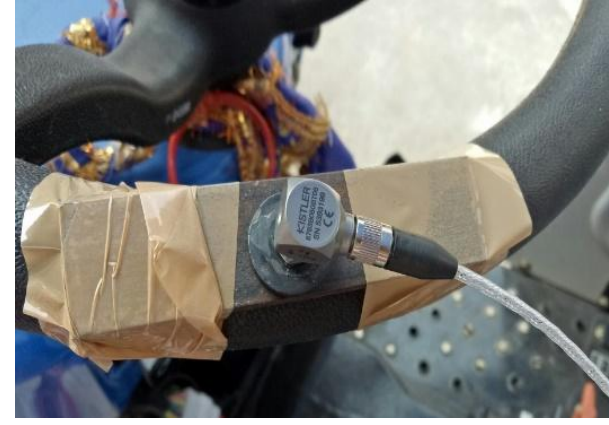

B

Fig.4 Accelerometer location for vibration measurement on a) seat cushion b) steering wheel

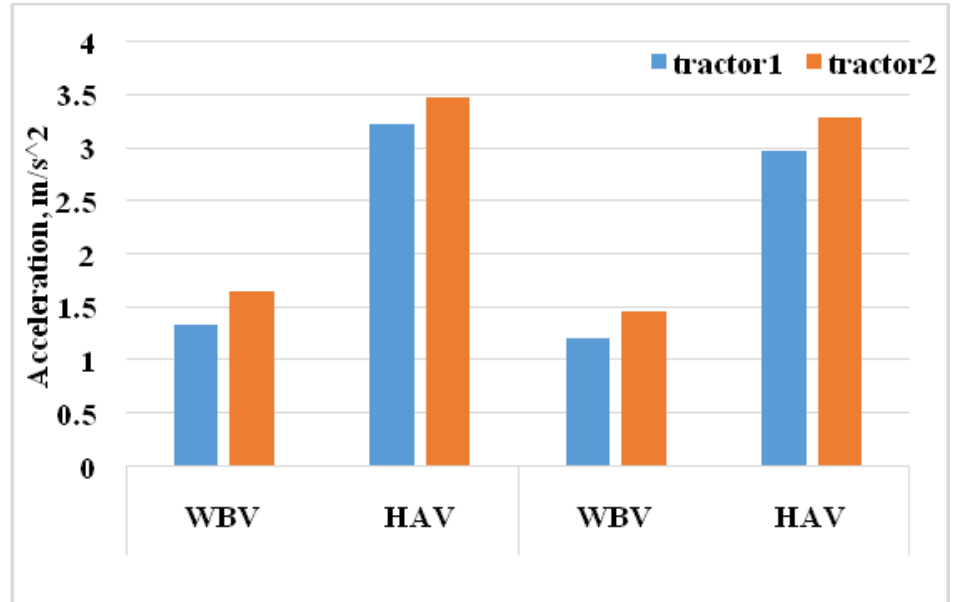

Fig 8.WBV and HAV in tractor 1 and tractor 2 during dry and wet field operation

The overall weighted RMS acceleration values were calculated as per ISO 2631:1991 for both WBV and HAV. For WBV, the vibration data collected was in the frequency range 1-80 $\mathrm{Hz}$ whereas for $\mathrm{HAV}$ the data collected was in the frequency range 1-1500
Hz. When these vibration values were compared with $8 \mathrm{~h}$ exposure value which defines the equal fatigue decreased proficiency boundaries, it was found that the fatigue hour for all treatments were within 4 hours (Table 12). 
It is concluded, by using rotavator, both primary and secondary tillage operation can be done simultaneously. Due to striking of rotavator blades at higher speed,vibration is transmitted to the operator through steering wheel and seat suspension. Hence, the objective of the study was decided to evaluate the whole body vibration and hand arm vibration during dry field and wet field operation. For this two tractors of same rated power, available at Odisha University of Agriculture and Technology, Bhubaneswar was selected. To analyse the effect of operator weight, three operators of weight $65 \mathrm{~kg}, 75 \mathrm{~kg}$ and $85 \mathrm{~kg}$ were selected for driving operation. Similarly, to evaluate the effect of speed of operation on vibration, three different speed of operations was selected for the study. During the test, the overall weighted RMS acceleration was analysed in $1 / 3^{\text {rd }}$ Octave band for WBV (1-80 Hz) and HAV (50-1000 $\mathrm{Hz})$. The results of the tests were the following:

1. With increase in speed of operation, the overall weighted RMS acceleration for both WBV and HAV were observed to be increased proportionally.

2. With increase in depth of operation, the overall weighted RMS acceleration values for both WBV and HAV were decreased significantly.

3. The overall weighted WBV was found to be less in case of $75 \mathrm{~kg}$ operator followed by $85 \mathrm{~kg}$ and $65 \mathrm{~kg}$ operator.

4. For dry field operation with rotavator, the WBV and HAV values were on higher side as compared to wet field operation.

5. While comparing the tractor of same rated power, the vibration values for both WBV and HAV was observed to be higher in case of tractor with higher hours of use.

6. The limit fatigue for all treatments were found to be within 4 hours while comparing with equal fatigue decreased proficiency boundaries for both WBV and HAV.

\section{References}

Anthonis, J.; Vaes, D.; Engelen, K.; Ramon, H.; Swevers, J. Feedback Approach for Reproduction of FieldMeasurements on a Hydraulic Four Poster. Biosyst. Eng. 2007, 96, 435-445.

Boshuizen HC, Bongers PM, Hulshof CTJ, 1990. Self-reported back pain in tractor drivers exposed to whole-body vibration. Int Arch Occup Environ Health 62: 109-115.

Bovenzi M, Betta A, 1994. Low-back disorders in agricultural tractor drivers exposed to whole-body vibration and postural stress. Appl Ergonom 25 (4): 231-241.

Dewangan, K. N., and V.K. Tewari. 2008. Characteristics of vibration transmission in the hand-arm system and subjective response during field operation of a hand tractor. Bio systems Engineering, 100 (4): 535-546.

Directive 2002/44/EC of the European Parliament and of the Council of 25 June 2002 on the minimum health and safety requirements regarding the exposure of workers to the risks arising from physical agents (vibration). 2002.

Goglia V, Gospodarić Z, Košutić S, Filipović D, 2003. Hand transmitted vibration from the steering wheel to drivers of a small four-wheel drive tractor. Appl Ergonom 34: 45-49.

Heidary B, Hassan-Beygi SR, Ghobadian B, 2013. Ergonomic characteristics and operator body fatigue against two-wheel tractor vibration. Int J Agr Crop Sci 5 (4): 370-376.

Hinz B, Menzel G, Blüthner R, Seidel H, 2010. Seat-to-head transfer function of seated men-determination with single and three axis excitations at different magnitudes. Ind Health 48: 565-583. https://doi.org/10.2486/indhealth.

MSWBVI-03.

Kumar A, Mahajan P, Mohan D, Varghese M, 
2001. Tractor vibration severity and driver health: A study from rural India. J Agr Eng Res 80 (4): 313-328.

Marsili, A., L. Ragni, G. Santoro, P. Servadio, G. Vassalini, PM-Power and machinery: innovative systems to reduce vibrations on agricultural tractors: comparative analysis of acceleration transmitted through the driving seat, Bios. Eng. 81 (2002) 3547.

Mehta, C.R., P.S. Tiwari, Varshney, Ride vibrations on a $7 ? 5 \mathrm{~kW}$ rotary power tiller, J. Agr. Eng. Res. 66 (1997) 169176 , https://doi.org/10.1006/jaer.1996.0131.

Oude Vrielink HHE, 2009. Exposure to whole-body vibration and effectiveness of chair damping in highpower agricultural tractors having different damping systems in practice. Report 2009-10-1. ErgoLab Research BV \& Profi 1-35

Prakash, A., G.S. Manes, A. Dixit, M. Singh, Performance status of rotavators being manufactured in Punjab, J Inst Eng India Ser A 94 (2013) 53-58, https:// doi.org/10.1007/s40030-013-0038-7.

Sam, B., K. Kathirvel, Vibration characteristics of walking and riding type power tillers, Bios. Eng. 95 (2006) 517-528.

Scarlett, A.J., J.S. Price, R.M. Stayner, Whole-body vibration: evaluation of emission and exposure levels arising from agricultural tractors, J. Terra 44 (2007) 65-73.

Servadio P, Belfiore NP, 2013b. Influence of tyres characteristics and travelling speed on ride vibrations of a modern medium powered tractor. Part II, Evaluation of the Health Risk. Agric Eng Int: CIGR Journal 15 (4): 132-138.

Village, J., C. Trask, Y. Chow, J.B. Morrison, M. Koehoorn, K. Teschke, Assessing whole body vibration exposure for use in epidemiological studies of back injuries: measurements, observations and self-reports, Ergon 55 (2012) 415424, https://doi.org/10.1080/00140139.2011. 643243.

Zaka, M.Z., Saleem, M.S., Khaliq, A., and Afzal, M., 2014, 'Effect of Hand Transmitted Vibration through Tractor during Ploughing Field', International Journal of Engineering Research and Applications, volume 4, issue 12(Part 6), pp 18-23.

\section{How to cite this article:}

Banasmita Behera, Ramani Ranjan Pradhan, Santosh Kumar Mohanty and Debaraj Behera. 2020. Study of Vibration Exposure from 55 HP Agricultural Tractors in Rotary Tillage Operations. Int.J.Curr.Microbiol.App.Sci. 9(02): 1181-1192. doi: https://doi.org/10.20546/ijcmas.2020.902.139 